\title{
The use of Shanon Weiners diversity index in the assessment of floral diversity and equitability of Neni-Nimo Watershed in Anaocha L.G.A. of Anambra State, Nigeria
}

\author{
Ezenwatah Ifeoma Susan 1, ${ }^{*}$, Ukpaka Chukwujekwu Gratius ${ }^{1}$, Onyemeka Regland Michael 2, Afulukwe Stella \\ Chinyere ${ }^{1}$ and Okoye Elochukwu Chidubem Sunday ${ }^{1}$ \\ ${ }^{1}$ Biological Science Department, Faculty of Natural Sciences, Chukwuemeka Odumegwu Ojukwu University, Uli, Nigeria. \\ ${ }^{2}$ Department of Botany, Faculty of Science, Lagos State University, Ojo, Lagos, Nigeria.
}

GSC Biological and Pharmaceutical Sciences, 2021, 16(04), 155-158

Publication history: Received on 14 July 2021; revised on 18 August 2021; accepted on 20 August 2021

Article DOI: https://doi.org/10.30574/gscbps.2021.16.2.0242

\begin{abstract}
The study on the floral diversity of Neni-Nimo watershed in Anaocha L.G.A. of Anambra State was conducted between November 2009 and July 2020. The aim of the study was to find out the species richness and the floral biodiversity of the watershed. In this study, the watershed was divided into three sites, the forested site, the fallow site and the current usage site. The experiment was laid out in a Randomized Complete Block Design. The ecological methods used in this study are the Point Centred Plotless Count sampling technique for areas dominated by trees while the Plot Count technique using quadrats were used for sampling the areas dominated by forbs, shrubs, climbers and grasses. The vegetation data collected was used to estimate the species richness of the different plant growth forms, the diversity and equitability of the various growth forms encountered were calculated using Shanon Weiners diversity index. The Shanno Weiners diversity index shows that the forested areas had the highest floral biodiversity than the fallow and current usage area. Regression analysis shows that a significant relationship exists between species abundance and floral biodiversity at a -value of $<0.05$ for all plant growth forms in the watershed except for grasses and as abundance increases, diversity also increases.
\end{abstract}

Keywords: Watershed; Shanno Weiners diversity index; Abundance measures; Flora biodiversity

\section{Introduction}

A watershed is a topographically delineated area, that is bounded by a drainage divide, which collects run-off from precipitation and primarily drains large amounts of underground water, melted ice, nutrients, sediments, toxins, from the soil into the nearby water bodies or stream channels [1]. Watershed is made up of a riparian area or riparian zone which is the strip of vegetation along a stream with distinct composition and density from the surrounding upland. Because of its topographic nature, it drains underground water and nutrients into nearby streams from the predominant landscape surface types [2]. Forests, roads, industries, churches, markets, hospitals, make up a watershed [3]. Under normal circumstances, a watershed is usually an evergreen forest, comprising of different life forms, in their natural habitat. Watersheds are unique and dynamic systems with various types of disturbances that affect them. These may include management activities such as livestock grazing, timber harvest, recreational use, and the creation of physical structures like clams and roads, or natural disturbances such as fire, and the action of water such as erosion [4].

The floral diversity of a watershed comprises all kinds of plants which is in existence within the watershed. Diversity promotes the stability of a community [5]. A diversity index also called phylogenetic index is a quantitative measure that reflects how many different types of species, found in a community or dataset can simultaneously give an account

\footnotetext{
${ }^{*}$ Corresponding author: Ezenwatah Ifeoma Susan

Biological Science Department, Faculty of Natural Sciences, Chukwuemeka Odumegwu Ojukwu University, Uli, Nigeria.
} 
of the phylogenetic relationship among the individual distribution. The value of a diversity index increases when the number of species is higher. Again, the diversity index is at the peak when all the species found in an area are equally abundant. Whenever diversity index is used in ecological studies the interest of the ecologist is usually focused on species, but some other groups such as genus and genus of the present species can be considered. Studies on biological diversity are essential as they will help in conservation and also help to mitigate climatic changes and maintain samples of unchanged biotic communities in their natural form for breeding.

As deforestation of watersheds increases, the biodiversity of watersheds decreases and becomes extremely depleted. This is the status of most watersheds in South-East Nigeria of which the watershed under study (Neni-Nimo watershed) is a case point. According to FAO [6], the available forest areas in Nigeria, if not properly managed by the appropriate government, will likely disappear by 2020. In Nigeria, especially Anambra state, the major practice that contributes to vegetation destruction in watersheds is mostly agricultural practices such as planting crops and animal grazing. Vegetation structure and diversity determine wildlife species diversity and abundance, and if a portion of habitat on which a species depends is damaged or destroyed, the breeding population of that species could be lost [7]. Therefore the aim of this study was to find out the species richness and the floral biodiversity of the watershed.

\section{Material and methods}

\subsection{Experimental site}

The experimental site of this research is the watershed of Ogbujilekwe stream bordering Neni and Nimo town in Anaocha L.G .A. of Anambra state. The Ogbujilekwe stream, as explained by the villagers and some of the farmers in the area, cuts across four major towns in Anambra State namely; Neni, Nimo, Oraukwu and Adazi-Nnukwu. The Neni-Nimo watershed falls within the humid tropical climate belt of Nigeria. The two seasons experienced in this area are the rainy season and the dry season. The maximum average rainfall is experienced during July and August. The mean annual rainfall is about $1500-2500 \mathrm{~nm}$.

\subsection{Experimental design}

The experimental design used in this research work is a Randomized Complete Block Design. The experimental area was divided into three sites, the forested site, the fallow site and the current usage site.

\subsection{Sampling technique}

Sampling techniques were used to determine the biodiversity of the various sites. Point Centred Plotless Count technique and the Point Count (Quadrant) was used in the study. Large tapes, wooden pegs and ropes were used for laying the plotless count sampling technique. Calipers and measuring tapes were used for measuring tree distances and diameter at the breast height of trees. The Point Centred Plotless Count sampling technique were used for areas dominated by trees while the Plot Count technique using Quadrats were used for sampling the areas dominated by forbs, shrubs, climbers and grasses.

\subsection{Statistical analysis}

The vegetation data collected was used to estimate the species richness of the different plant growth forms, which include trees, forbs, shrubs, grasses and climbers that are in existence on the watershed. The diversity and equitability of the various growth forms encountered were calculated using Shanon Weiners diversity index. Regression analysis was used to evaluate the nature of the relationship between the number of species and diversity indices for trees, shrubs, forbs, climbers and grasses.

\section{Results}

Considering species richness (see Table 1), the forested site was the richest in tree species, the trees and the grasses had the highest Shannon Weiners indices of 2.7 and 2.5 respectively, while the climbers had the least index of 1.2 for the forested areas. For the fallow areas, the shrubs scored the highest diversity index of 3.0, while climbers and trees had the least index of 1.8. For the current usage area, shrubs had the highest diversity index of 0.7 while forbs had the least index of 0 .

From the regression analysis, there is clear evidence that diversity is dependent on the number of plants or species abundance. Table 2 shows the regression analysis for the various growth forms and their diversity indices is significant 
for all the growth forms because the p-value is $0.000<0.05$ except for grass which has a p-value of 0.719 which is greater than 0.05 .

For the trees, the R-square which is the coefficient of determination is 0.576 which means the independent variable has $57.6 \%$ strength, explaining the dependent variable diversity. For the shrubs species and their diversity indices, the Rsquare is 0.895 which means the independent variable number of shrubs is $89.5 \%$ strength, explaining the dependent variable diversity. The R-square for forbs species and their diversity indices is 0.967 which means the independent variable is $96.7 \%$ strength, explaining the dependent variable which is diversity. The R-square which is the coefficient of determination for climbers and their diversity indices is 0.548 which means the independent variable is $54.8 \%$ strength. The grasses had an R-square of 0.004 and $0.4 \%$ strength of explaining the dependent variable which is diversity.

Table 1 Shannon Wieners Index of growth forms across the sites of the studied watershed

\begin{tabular}{|l|c|c|c|c|}
\hline Site & Growth Forms & Shannon Wieners Index & Hmax & Equitability \\
\hline \multirow{4}{*}{ Forested } & Trees & 2.77 & 3.58 & 0.77 \\
\cline { 2 - 5 } & Shrubs & 2.20 & 3.04 & 0.72 \\
\cline { 2 - 5 } & Forbs & 2.44 & 3.00 & 0.88 \\
\cline { 2 - 5 } & Climbers & 1.23 & 2.48 & 0.47 \\
\cline { 2 - 5 } Fallow & Grass & 2.59 & 2.48 & 1.00 \\
\hline \multirow{5}{*}{} & Trees & 1.83 & 2.20 & 0.85 \\
\cline { 2 - 5 } & Shrubs & 3.02 & 3.29 & 0.90 \\
\cline { 2 - 5 } & Forbs & 2.96 & 3.29 & 0.80 \\
\cline { 2 - 5 } & Climbers & 1.89 & 2.08 & 0.86 \\
\cline { 2 - 5 } & Grass & 3.10 & 3.04 & 1.00 \\
\hline \multirow{5}{*}{} & Shrubs & 0.75 & 1.94 & 0.36 \\
\cline { 2 - 5 } & Forbs & 1.68 & 2.48 & 0.60 \\
\cline { 2 - 5 } & Climbers & 1.58 & 1.60 & 0.90 \\
\cline { 2 - 5 } & Grass & 0.43 & 1.79 & 0.25 \\
\hline
\end{tabular}

Table 2 Regression analysis for the Growth forms of the Watershed

\begin{tabular}{|l|c|c|c|c|l|}
\hline Growth forms & R Square & Df & Mean Square & F & Sig. \\
\hline Trees & 0.576 & 1 & 0.444 & 52.523 & $0.000 \mathrm{~b}$ \\
\hline Shrub & 0.891 & 1 & 0.262 & 255.054 & $0.000 \mathrm{~b}$ \\
\hline Forbs & 0.966 & 1 & 0.106 & 855.084 & $0.000 \mathrm{~b}$ \\
\hline Climbers & 0.506 & 1 & 0.128 & 13.310 & $0.004 \mathrm{~b}$ \\
\hline Grasses & -0.029 & 1 & 0.000 & 0.132 & $0.719 \mathrm{~b}$ \\
\hline
\end{tabular}

a. Dependent Variable: diversity indices (Pi lnp)

b. Predictors: (Constant), Number of Trees, shrub, forbs, climbers, grasses

\section{Discussion}

The assessment of the NENI-NIMO watershed, using Shannon Weiners diversity indices shows that the forested area, had the highest species richness and diversity index when compared with the current usage site and the shallow site. The tree species scored the highest diversity indices among all the species in the forested area in the watershed, but the 
forbs scored the highest evenness indices or equitability of 1 . At the fallow site, the grasses and the forb species had the highest diversity indices with only grasses having the highest evenness or equitability of 1 . For the current usage area, the forb species had the highest diversity indices while the climbers had the highest evenness indices or equitability of 1. From the regression analysis conducted, to check the nature of the relationship between species richness and diversity indices, it was proved that the number of species or species richness increases, the diversity of the plant species, also increases. This was true for all the growth forms in the watershed, except for the grasses, which did not follow any model.

\section{Conclusion}

The assessment of the NENI-NIMO watershed using Shannon Weiners diversity indices show that the forested site was the richest in tree species. While the shrubs were the richest species for the fallow and current usage area. From the regression analysis, there is a clear evidence that diversity is dependent on the number of plants or species abundance. Conversing these species in will help mitigate climatic changes and maintain the biotic communities in their natural form for breeding.

\section{Compliance with ethical standards}

\section{Acknowledgments}

The Authors will like to appreciate Prof. Ukpaka of the department of Biological Science Department, Chukwuemeka Odumegwu Ojukwu University for his contributions that resulted in the success of this research work.

\section{Disclosure of conflict of interest}

The authors disclose that there is no any form of conflict throughout the research work and the publication of this manuscript.

\section{References}

[1] Enwelu IA, Asogwa NP, Nwalieji HU, Ezeano CI. Assessment of constraints to cocoyam consumption in selected communities of Enugu State, Nigeria. IMPACT: Int. J. Res. Appl. Natl. Social Sci. 2014; 2(3): 31-40.

[2] Kunstler G, Curt T, Lepart J. Spatial pattern of beech (Fagus sylvatica L.) and oak (Quercus pubesces Mill) seedlings in natural pine (Pinus sylvestris L.) woodlands. Eur Journal Forest Research. 2004; 123: 331-337.

[3] Ukpaka CG, Nnabude PC. Species Composition of a Degraded Watershed in Amawbia, Anambra State, Nigeria, American Journal of Plant Biology. 2018; 3(1): 1-7.

[4] Evrendileka F, I Celik, S Kilic. Changes in soil organic carbon and other physical soil properties along adjacent Mediterranean forest, grassland and cropland ecosystems in Turkey. J. Arid Environ., 2004; 59: 743-752.

[5] Hutchinson MF. A new procedure for gridding elevation and stream line data with automatic removal of pits. Journal of Hydrobiology, Australia. 1989; 106: 211-232.

[6] Food and agricultural organization. Forest trees and people. Forestry topics. Report no 2 FAO, United Nations. 1985; 40.

[7] Miller TF, Mlandenof DJ, Clayton MK. Old growth northern hardwood forest: Spartial autocorrelation and patterns of understory vegetation. Ecological Monogram. 2002; 72: 487- 503. 